\title{
The Problems of Remediation of Chemical Disasters and Their Solutions in Latvian Ports
}

\author{
Ivars Metra, State Fire and Rescue Service of Latvia, Jelena Sulojeva ${ }^{1}$, Vladimirs Jemeljanovs ${ }^{2}$, Janis Bartusauskis ${ }^{3}$, \\ ${ }^{1-3}$ Riga Technical University
}

\begin{abstract}
The aims of the study are to identify common problems of chemical accident liquidation and to find solutions to them.

During research, the authors have analyzed information on the most characteristic chemical accidents in ports of Latvia. The authors of the paper have also examined issues related to typical chemical emergency liquidation and considered the causes and solutions of problems, which resulted in the summarizing of important information on major ports of Latvia, including characteristics of activities.

The authors have put forward proposals on the ways of overcoming the above-mentioned problems and designed a practical training course plan for chemical accident liquidation.
\end{abstract}

Keywords: Issues of chemical emergency abolition, ports of Latvia, security measures, transit of goods.

\section{INTRODUCTION}

The definition of a port is as follows: part of the land territory of Latvia defined by boundaries, including artificially created banks, and such part of inland waters, including inner and outer road steads and fairways in the port entrance, which are set up for the servicing of ships and passengers, for the conduct of freight, transport and expedition operations and other economic activities [5].

Every year port development takes place and there is also a growing cargo turnover, which obviously causes increased risks and dangers, as it may cause more breakdowns, technical errors and accidents.

Therefore, in order to promote safety measures, it is necessary to evaluate the risks and possible accident scenarios, chemical substances and chemical products that are stored in the port territory, if necessary, to be able to react quickly and to prevent accidents or to prevent risks.

The aims of the study are to determine the most frequent problems of chemical accidents and to find respective solutions.

The studied topic of chemical accidents is limited by the nature and development dynamics of accidents, because even at one or several variable circumstances, development of accidents is not predictable. It should be noted that during the research it was not possible to perform the practical simulation of chemical leak, thus creating additional constraints for the study of selected topic.

\section{II.CASE STUDY AND STATISTICS}

Since ancient times, Latvia has been linked to the sea, transit of ships and goods. The ports of Latvia have not lost their importance over time and in recent years they have developed and are able to host significant quantity of goods [12].

Many transported freights are harmless and safe (they do not compromise the safety of the public and environment); however, a large part of transported freights is different, because their physical and chemical properties are classified as dangerous freights. As a result of an accident, these dangerous freights may lead to increased risks for human life or health, property and environment pollution.

According to the Law on the Movement of Dangerous Goods, dangerous goods are goods, which due to the properties thereof may cause an explosion, fire, human or animal death, falling ill, poisoning, irradiation or burns, damages to the property or may cause harm to the environment during carriage or temporary storage process related thereto and which concurrently is deemed dangerous in accordance with the international agreements [3].

Only those goods are considered dangerous that comply with the criteria set out in the United Nations and may be classified in accordance with the Agreement between the European countries for the transport of dangerous goods.

During production, use, storage and transport of dangerous chemical substances, there is a risk that a human or equipment error may result in a threat of fire, explosion or leakage by causing damage to people and the environment, as well as may cause material losses. Nowadays, more than 40000 chemicals are used in the industry and there is always a possibility that a small or large accidental leakage can occur [9].

In accordance with the US Public Interest Research Group (PIRG) data, in Dow Chemical Company, which is the second largest chemical company in the world, from 1990 till 2003 in chemical industrial facilities 2562 accidents occurred ( 2 emergency situations each day) [10].

The reactions of the dangerous chemical substance depend on storage of substance, transportation and other conditions.

In the case of an emergency in a dangerous object, chemical threat zone may include large areas with a large number of inhabitants.

Even if a safety rule in chemical plants is taken into consideration, there is a high risk of accidents and, as a result, the threat to the staff, residents and the environment.

During the investigation of chemical accidents, it has found that chemical emergency causes may be associated with human activities, technological installations or equipment failures, as well as improper storage of chemicals [14].

One of the US Environmental Protection Agency publications provided more detailed examples of occurred 
emergencies and analysed the reasons of cyclic nature of chemical accidents:

Inadequate hazard review or process hazard analysis; installation of pollution control equipment; use of inappropriate or poorly designed equipment; inadequate indications of process condition and warnings went unheeded [11], [16].

Emergencies that occurred earlier have made impulsion in chemical accident prevention area; therefore, European Union has adopted the Seveso Directive, the purpose of which is, firstly, to prevent major accidents involving dangerous substances and, second, to limit the consequences of such accidents on people (health and security issues) and the environment. The requirements of Seveso Directive have been also included into the national legislation of the Republic of Latvia on the Regulation No. 532 "Regulations regarding the Procedures for Industrial Accident Risk Assessment and Risk Reduction Measures" (contains also numerically smallest qualifying quantities of dangerous substances) [8].

Referring to the information on port activities in Latvia, we can conclude that a major hazardous cargo turnover is made in three major ports - Ventspils, Riga and Liepaja, which basically deal with transit operations, and those ports have been granted a free economic zone status. Therefore, the main indicators of statistical data on freight turnover are about three major ports.

During the analysis of the information available in the Baltic Sea east coast ports, results have shown that these ports experience a significant increase in the volume of shipped cargos and compared to the previous year statistics it is clearly visible (See Fig. 1) [12].

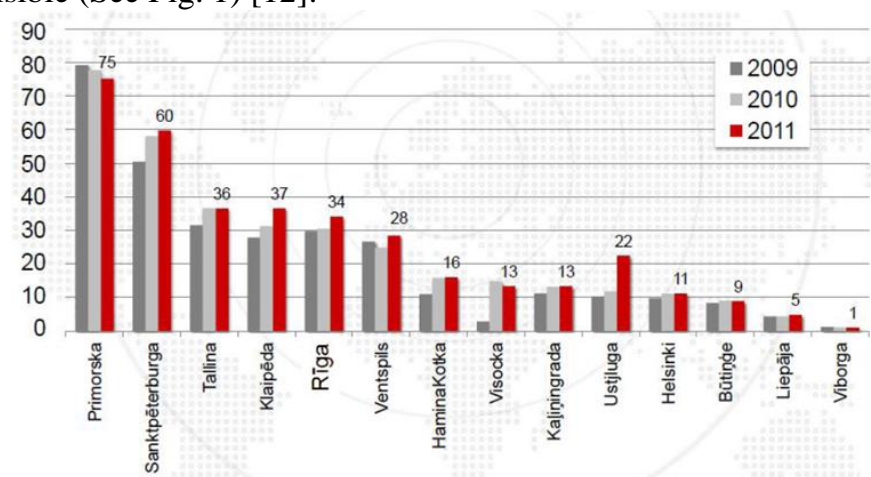

Fig. 1. Cargo turnover in the Baltic Sea east coast ports (million tons).

Competition for the transshipped goods is not only between ports, but also between countries, where Latvia takes the second place in 2011 on the eastern shore of the Baltic Sea with handling of more than 67 million tons per year [12].

According to the available statistics for the first 11 months of 2012, the situation is similar as in previous years. The ports are located next to each other behind the leading Russian and other Baltic ports [12].

Common transshipped goods in Latvian ports can be divided into 6 groups:

1. petroleum products (diesel, crude oil, petroleum resins, heavy fuel, other oil products),
2. dangerous chemical cargoes - different types of substances that can cause damage and risks to the environment and human health (coal tar, acrylonitrile, methyl tertiary butyl ether, etc.),

3. liquefied gases as liquid bulk cargo (propane, carbon dioxide, etc.),

4. dangerous goods in packaging - which correspond to one of the classes of the IMDG Code 9 classes (flammable liquids, gases, toxic substances, etc.),

5. dangerous bulk cargoes - self-igniting, oxidizing and other substances (ammonium nitrate, sunflower seed expeller, fish meal, etc.),

6. solid bulk cargo - less dangerous to the environment and population than the above-mentioned cargoes (wood in chips or briquettes, coal).

On the basis of the information, we can conclude that the most dangerous goods in major ports of Latvia are petroleum products and materials, which can be hazardous as bulk cargoes; however, only oil products from these two groups can cause chemical pollution and endanger the environment and population.

In the period from 1999 to 2012, in general 15 accidents occurred in the territory of Latvia, which caused chemical spills. Six of them took place in the ports of Latvia and the sea [13].

\section{A. The Main Challenges for the Liquidation of Chemical Accident Consequences}

In any emergency liquidation operations, there are difficulties that hamper the effective fulfillment of operations and affect the outcome. The different types of problems arising during the liquidation of emergency consequences are unpredictable and are addressed during the event; however, it is possible to solve some of problems in the preventive phase.

One of the most dangerous accidents is the one that involves chemical substances and products, which are a threat to the society and environment. Although such accidents do not happen often, when these incidents occur they increase risk, as they may cause pollution.

The liquidation of consequences from chemical accidents (rescue works) depends on actions of staff responsible for the organization, staff training to respond during an accident, as well as professional activities of operational services and experience in similar situations. The activities of staff involved in the rescue work (namely, the State Fire and Rescue Service (SFRS)) are regulated by laws and regulations, which state that during rescue measures the first priority is to rescue people. Rescuing of people is part of a set of measures, which fire fighters - rescuers carry out, to evacuate from endangered zone humans and /or animals (if they cannot get out of risk zone without help), as well as provision of first aid to wounded casualties. Rescuing of people is typically associated with the measures, which include the evacuation organised exit, export or transfer outside risk areas [4].

During liquidation of consequences from chemical accidents as well as from other types of accidents, different types of issues are raised (see Fig. 2). 


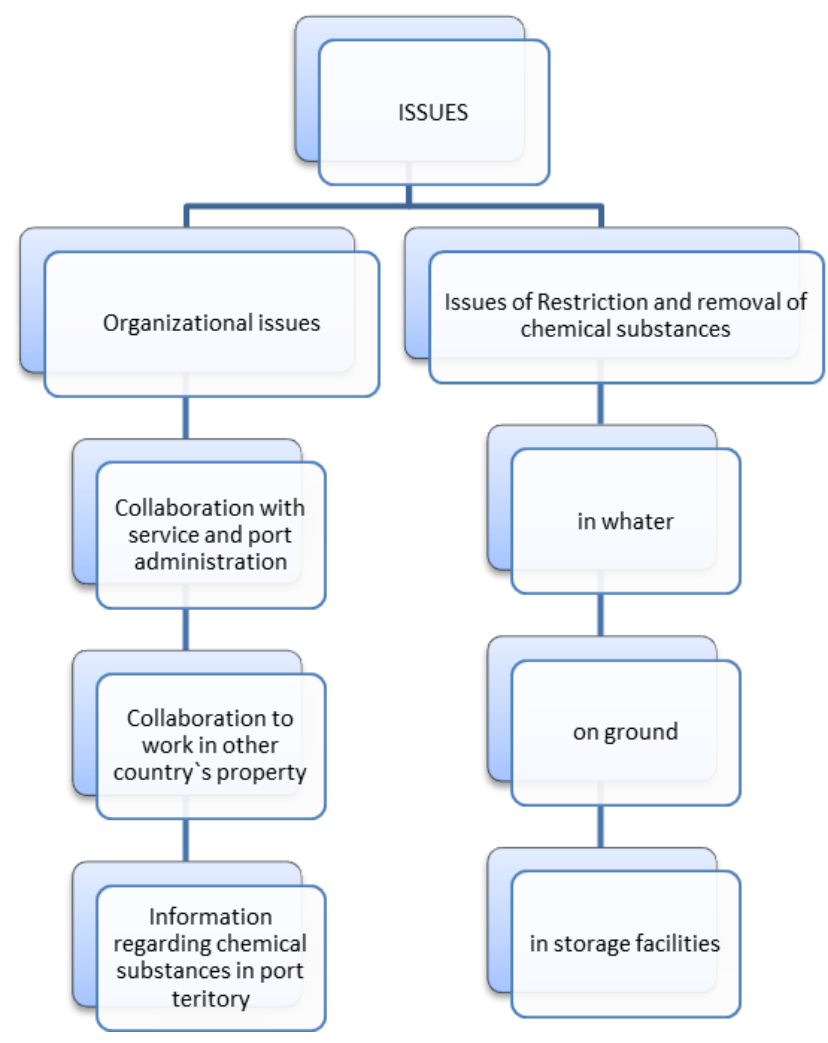

Fig 2. The problem of the consequences of chemical accidents.

\section{The MAIN Challenges FOR THE LiQuidation OF CHEMICAL ACCIDENT CONSEQUENCES}

Localization, containment and neutralisation of chemical substance leakage source may include the following activities:

1. Localization of primary and secondary cloud of dangerous chemical substances;

2. Localization of leaks from hazardous chemical substances;

3. Neutralisation of dangerous chemical substances leak [2].

\section{A. The Proposals to Address Issues}

Analysis of statistics shows that chemical emergency in port territories does not happen often, but, as known, industrial and technological processes take place in ports, and there is also risk that chemical emergency may occur.

During liquidation of consequences in case of accident with chemicals, there is a possibility that various kinds of problems can occur. Therefore, it is necessary to think about evaluation and solution of these problems.

Evaluation of accident consequences is performed for each organization, where the main points are set (see Fig. 3), as well as different risks are evaluated, which can also help to resolve issues in the liquidation of an accident.

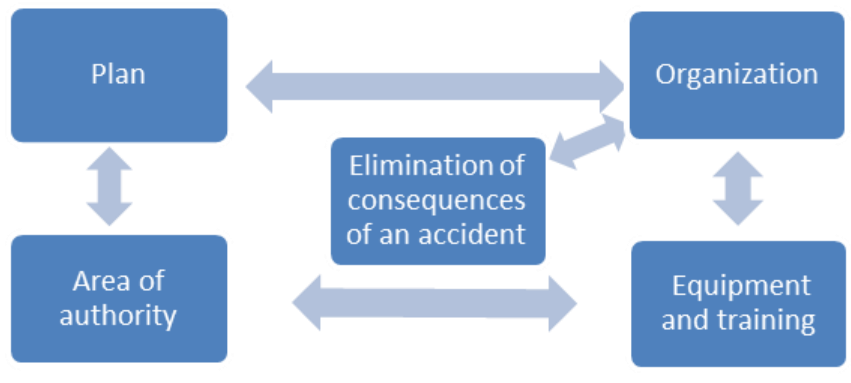

Fig. 3. The consequences of an accident assessment scheme.

\section{B. Organisational Issues}

We believe that organisational issues are of major importance, because without information, training and cooperation the liquidation of chemical accident consequences cannot be initiated. Therefore, first it is necessary to prevent problems exactly in this group.

\section{Cooperation with Authorities and Port Administration}

One of the main issues is the cooperation between authorities and organisations, as well as port administration and employees who participate in the liquidation of chemical accident consequences. The problem is mainly related to communication between authorities and exchange of information, because on a daily basis such level communication does not exist; however, in large accidents the cooperation between authorities affects the quality and speed of liquidation of consequences from accidents.

In order to clarify the situation and to draw conclusions on elimination of chemical accident consequences, each participating authority and institution must assess their work, as well as work of other involved services and organisations.

It should be mentioned that operational services should learn from the lessons of previous calamities and accidents in ports in order to avoid future mistakes and work more effectively.

For example, we could mention the fact that many countries form databases, which can be useful for industry representatives, operational services and research institutions for obtaining statistical information about industrial chemical accidents. There are such databases as the European Commission's Major Accident Reporting System (MARS), German database ZEMA, ARIA in France, MHIDAS in Britain and TNO FACTS database in the Netherlands [1].

In addition, it is worth mentioning the U.S. Environmental Protection Agency's (EPA) large practice in the investigation of major industrial accidents. EPA organises and carries out a comprehensive study, which involves experts from various industries to accurately investigate accidents, during which scientific evidence and verifiable facts are searched for causes that led to accidents. When the investigation process is completed, an accident investigation report is written, which contains an accident scenario and recommendations given by experts for various industries (labour safety, industry and 
technology, legislation, etc.) in order to prevent similar events in the future [17].

One of the most important challenges for resolving issues is training, which involves a number of authorities and organisations. In everyday work, such high-level communication and cooperation between authorities and organisations are not formed; therefore, during elimination of accident consequences good cooperation cannot be developed so well. It is therefore necessary to carry out extensive training, which involves more authorities and organisations that in real accidents will operate for liquidation of consequences.

\section{Collaboration to Work in Property owned by Other Countries}

Cooperation with other countries is very important during the elimination of chemical accident consequences. Ships that sail in the Latvian ports often comprise the property of other countries, so when accidents occur, strict measures and cooperation with the ship's captain must be taken into consideration.

One of the most important aspects is that ship's crew does not speak English, so a situation when a ship's captain is not on board makes difficult communication and exchange of information. Problems arise that are associated with the lack of time and assessment of the situation. For problem solving there are many possible and different scenarios; however, the most effective one could be the cooperation agreement between the port administration, owner of the ship, SFRS, and a country. An agreement could define that under unforeseen circumstances and in case of accidents, which may pose a threat to the environment and people, the process of liquidation of accident consequences can be initiated without request of permits. The second thing, which must be ensured, is that ship's owners and a country concerned have information on the quantities of substances and products on board the vessel and at arrival in port this information must be transferred to the port administration, which makes it available in emergency situations.

\section{E. Information on Chemical Substances in the Port Territory}

Liquidation of chemical accident consequences and rescue operations are complicated by the fact that our firefighting and rescue services do not have accurate information about quantity of chemical substances in port territories.

As soon as it becomes clear that the situation is serious, authorities and heads of institutions are immediately informed, additional employees are called upon, chemical equipment is taken and teams drive to the scene. Action headquarters are organized, the National Armed Forces and Naval Forces Coast Guard Service of Coast Guard ship and personnel are mobilized. The action headquarters consider and evaluate operations for liquidation of spill consequences of chemical substances and design a plan for better organisation of rescue work.

Therefore, it should be necessary to create a united system or program that could reflect quantities and type of chemical substances in the port territory.

\section{F. Chemical Containment and Disposal Problems}

The second most important problem group is chemical containment and disposal problems. Unlike organisational problems, these problems might occur during direct work, so they can make complicate the liquidation of the consequences. Chemical accidents do not happen often; however, they may appear in different places and weather conditions. In order to carry out liquidation of chemical accident consequences in different situations appropriate equipment is needed.

Equipment in stevedoring companies established in the territory of the port, as well as on ships carrying dangerous chemical cargos is suitable for primary work to ensure that dangerous substances or products will not cause much damage. More professional equipment belongs to different services involved in liquidation of chemical accident consequences.

Spreading of chemical substances in case of leak depends on:

1. Chemical characteristics (density, viscosity and solubility in water);

2. Size of a leakage;

3. Place of incident;

4. Weather conditions;

5. Surrounding environment.

\section{CONCLUSIONS AND PROPOSALS}

As a result of the study, main information is collected about the largest Latvian ports, about types of activity, nature and characteristics. Main problems are generally defined to mitigate chemical accident consequences, and they are interpreted from a mathematical point of view. The authors have outlined their vision for resolution of problems, as well as developed a practical training plan on chemical accident liquidation process.

Within the framework of the research, the authors have come to the following conclusions:

1. The number of received calls to the SFRS regarding the leakage of dangerous chemical substances is low, but potential effects can be heavy. SFRS statistics shows that in recent years the amount of rescue work involving dangerous substances is increasing;

2. There is a necessity to ensure practical training for fire fighters and rescuers to perform work with dangerous substances professionally and safely, as well as introducing solutions to prevent problems related to possible chemical leakage in the Latvian ports.

3. In the objects that may pose increased danger risks, operational services should develop practical and tactical skills that are necessary in case of leakage of dangerous chemical substances.

4. In accordance with the state civil protection plan, a responsible institution shall make an evaluation of undertaken measures.

5. In Europe and other countries, databases are used to collect information on previous accidents and incidents that can be used by authorities to learn from causes and consequences of previous incidents. 
6. In some countries, after major accidents comprehensive studies are conducted, which reflect causes and scenarios of accidents, as well as experts describe recommendations for different industries. In Latvia, this practice does not exist.

\section{A. Proposals:}

1. Summarized information can be used as an informative material for SFRS employees;

2. At major ports, it is necessary to carry out risk assessment in order to obtain detailed information and a description of industrial objects or vessels risk scenarios, their implementation probability and circumstances, in which they may occur.

3. After evaluation of undesirable events, more ports will be provided with information on probability of possible accidents, as well as operational services will have opportunity to plan material and technical resources for an effective elimination of accident consequences.

\section{REFERENCES}

[1] European Agency for Safety and Health at Work. Emergency Services: A Literature Review on Occupational Safety and Health Risks. 2011, 80.lpp;

[2] A. V. Vrubḷevskis, A. P. Ermanis, G. V. Kotovs, A. D. Buḷba, N. Plēgermanis, M. Lutbāržs. Metodiskie ieteikumi par rīcību ḳīmiskajās avārijās - Minsk, Riga, Vilnius, 2008-2009 - 48.lpp;

[3] Legislation website Likumi.lv "Law on the Movement of Dangerous Goods" January 2011. [Online]. http://likumi.lv/doc.php?id=220516 [Accessed: Oct. 11, 2013].

[4] State Fire and Rescue Service of Latvia. Regulation Nr. 3. July. 12 2006. Ugunsgrēku dzēšanas un glābšanas darbu veikšanas kārtība. SFRS internal normative act. SFRS internal library;

[5] Legislation website Likumi.lv "Law on Ports" March 2001. [Online]. Available: http://likumi.lv/doc.php?id=57435 [Accessed: Oct. 11, 2013].

[6] Home page LU Faculty of Geography and Earth Sciences „Anthropogenic disasters", Lecture [Online]. Available: http://www.geo.lu.lv/fileadmin/user_upload/lu_portal/projekti/gzzf/vide unilgtspejigaattistiba/VidZ1010/09.LEKCIJA-

Antropogenas_nelaimes.pdf [Accessed: Dec. 20, 2012].

[7] Freeport of Ventspils Home page "Free Port Today" [Online]. Available: http://www.portofventspils.lv/en/free port tody/ [Accessed: May. 16, 2012].

[8] European Commission Home page "Chemical Accidents (Seveso II)" [Online]. Available: http://ec.europa.eu/environment/seveso/index.htm. [Accessed: Nov. 19, 2012].

[9] Pollution Issues Home page "Disasters: Chemical Accidents and Spills" [Online]. Available: http://www.pollutionissues.com/Co-Ea/DisastersChemical-Accidents-and-Spills.html [Accessed: Nov. 11, 2012].

[10] Students for Bhopal Home page "Dow Chemical" [Online]. Available: http://old.studentsforbhopal.org/DirtyDow.htm [Accessed: Nov. 10, 2012].

[11] James C. Belke "Recurring Causes of Recent Chemical Accidents" Plant Maintenance Resource Center - Home page. September 1998. [Online]. Available: $\quad$ http://www.plant-maintenance.com/articles/ccps.shtml [Accessed: Nov. 17, 2012].
[12] Freeport of Riga Board - Home page, Presentation "Freeport of Riga" [Online]. Available: http://www.rop.lv/lv/media-lv/prezentacijas.html [Accessed: July. 16, 2012].

[13] State Fire and Rescue Service of Latvia - Home page, Statistics [Online]. Available: http://vugd.gov.lv/lat/aktualitates/statistika [Accessed: Jan. 03, 2013].

[14] Norman S. Wei "The Root Causes of Chemical Accidents" Pollution Engineering Magazine. July, 2008 [Online]. Available: http://www.pollutionengineering.com/Articles/Column/BNP GUID 95-2006_A 10000000000000380622 [Accessed: Nov. 13, 2012].

[15] Ministry of Transport of Latvia, Department of transit policy, Transit Latvia, "Ostas" [Online]. Available: http://www.transport.lv/?sadala=107 [Accessed: July. 09, 2012].

[16] Transport Accident And Incident Investigation Bureau of Latvia - Home page "Transporta nelaimes gadijumi un incidenti" [Online]. Available: $\quad$ http://www.taiib.gov.lv/uploads/drosibas_p 2011.pdf [Accessed: July. 13, 2012].

[17] U.S. Environmental Protection Agency. - Home page [Online]. Available: http://www.epa.gov/osweroe1/publications.htm [Accessed: Nov. 13, 2012].

Ivars Metra. Since 2011, Ivars Metra has been working as an Inspector at the State Fire and Rescue Service of Latvia, Administration of Riga Region for Fire Monitoring and Civil Protection. In 2011, he graduated from Fire Safety and Civil Protection College, obtaining a specialty - Technician of Safety and Civil Protection. In 2013, he graduated from Riga Technical University, obtaining a qualification of Fire Protection and Civil Defence eEngineer.

Address: 3 Maskavas Street, Riga, LV-1050, Latvia

E-mail: ivars.metra@vugd.gov.lv

Vladimirs Jemeljanovs, Professor of the Institute of Labour Safety and Civil Defence at Riga Technical University, the Faculty of Engineering Economics and Management. In 1997, he was awarded a Degree of Doctor of Engineering Sciences (Dr.sc.ing.) by Riga Technical University. He delivers lectures on civil defence and firefighting. He specialises in work safety, improvement of civil protection, fire prevention system efficiency and firefighting efficiency.

Address: 6 Kalnciema Street, Riga, LV-1048, Latvia

E-mail: Vladimirs.Jemeljanovs@ rtu.lv

Jelena Sulojeva, Assistant Manager for the Study Process at the Institute of Labour Protection and Civil Defence and Lecturer at Riga Technical University. In 2011, she was awarded a Degree of Doctor of Economics (Dr.oec.) by Riga Technical University. She was a member of the board at SVD Group, Ltd. (2010-2011), Assistant Professor and Head of Business Department at the Latvian Business College (2008-2010).

Address: 6 Kalnciema Street, Riga, LV-1048, Latvia

E-mail: Jelena.Sulojeva@ rtu.lv

Janis Bartusauskis, Lecturer and Head of Civil Defence Laboratory at the Institute of Labour Safety and Civil Defence, Riga Technical University, the Faculty of Engineering Economics and Management. He received a Master Degree in Labour Safety from Riga Technical University in 2007. He delivers lectures in the field of labour safety. He specialises in work safety and aspects of labour protection, as well as risk assessment.

Address: 6 Kalnciema Street, Riga, LV-1048, Latvia

E-mail: dcai@rtu.lv, mob.ph.: +37122023337. 
